Jurnal Keperawatan Silampari

Volume 5, Nomor 1, Desember 2021

e-ISSN: 2581-1975

p-ISSN: 2597-7482

DOI: https://doi.org/10.31539/jks.v5i1.3015

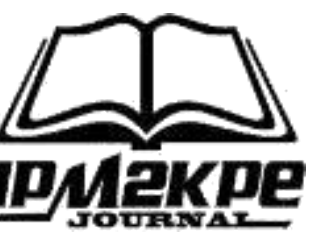

\title{
PERMASALAHAN YANG MEMPENGARUHI KECEMASAN TENAGA KESEHATAN DALAM PENANGANAN COVID-19
}

\author{
Kgs. Muhammad Faizal ${ }^{1}$, Ardiansyah ${ }^{2}$ \\ Sekolah Tinggi Ilmu Kesehatan Citra Delima Bangka Belitung ${ }^{1,2}$ \\ faizalcd14@gmail.com ${ }^{1}$
}

\begin{abstract}
ABSTRAK
Penelitian ini bertujuan untuk mengetahui permasalahan apa saja yang mempengaruhi kecemasan tenaga kesehatan dalam penanganan COVID-19. Desain penelitian ini menggunakan desain penelitian kuantitatif dengan pendekatan cross-sectional. Hasil penelitian didapatkan bahwa beberapa faktor yang menjadi dugaan permasalahan kecemasan dalam penanganan COVID-19 yang memiliki hubungan adalah usia $(0,044)$, status keluarga $(0,037)$ dan pengetahuan tenaga kesehatan $(0,000)$. Sedangkan variabel jenis kelamin, pendidikan, masa kerja, saran dan prasaran tidak ada hubungan dengan permasalahan kecemasan tenaga kesehatan dalam penangan COVID-19. Simpulan, ada hubungan usia, status keluarga, dan pengetahuan terhadap kecemasan penanganan COVID19.
\end{abstract}

Kata Kunci: COVID-19, Kecemasan, Tenaga Kesehatan

\section{ABSTRACT}

This study aims to find out what problems affect the anxiety of health workers in handling COVID-19. This research design uses a quantitative research design with a cross-sectional approach. The results of the study found that several factors that were suspected of having anxiety problems in handling COVID-19 that had a relationship were age (0.044), family status (0.037), and knowledge of health workers (0.000). At the same time, the variables of gender, education, years of service, advice, and infrastructure have no relationship with the anxiety problems of health workers in handling COVID-19. In conclusion, there is a relationship between age, family status, and knowledge of anxiety handling COVID-19.

Keywords: COVID-19, Anxiety, Health Workers

\section{PENDAHULUAN}

Penambahan jumlah kasus COVID-19 berlangsung cukup cepat sampai dengan tanggal 28 Oktober 2020, secara global dilaporkan sebanyak 43.540 .739 orang terkonfirmasi positif COVID-19 dan 1.160.650 orang (2,6\%) kasus meninggal dunia (WHO, 2020). Di Indonesia sendiri, mulai dari tanggal 30 Desember 2019 sampai 28 Oktober 2020 terdapat 400.483 orang terkonfirmasi positif COVID-19 dan 13.612 orang $(3,4 \%)$ kasus meninggal dunia (Kemenkes, 2020). Data kematian yang disebabkan COVID-19 selalu ada setiap harinya tercatat pada tanggal 28 Oktober 2020 di dunia sebesar 2,6 \% dan di Indonesia sebanyak 3,4 \% (WHO, 2020). Kematian bukan hanya terkena pada masyarakat melainkan juga tenaga kesehatan yang selalu bertemu pasien yang terkonfirmasi positif, sehingga tenaga kesehatan timbul rasa cemas yang nantinya akan 
menurunkan imunitas. Menurut hasil penelitian 50,4\% tenaga kesehatan mengalami gejala depresi dan 44,6\% memiliki gejala kecemasan karena perasaan tertekan (Fadli et al., 2020).

Meningkatnya angka kasus positif dan kematian pasien COVID-19 berdampak pada gangguan mental seperti kecemasan, ketakutan, stress, depresi, panik, kesedihan, frustasi, marah serta menyangkal (Huang et al., 2020). Keadaan tersebut bukan hanya dirasakan oleh masyarakat saja, namun juga dirasakan oleh tenaga kesehatan seperti dokter dan perawat. Penelitian Huang et al., (2020) didapatkan hasil 1.257 tenaga kesehatan mengalami gangguan mental di 34 rumah sakit di Tiongkok dengan hasil gejala depresi $50 \%$, kecemasan $45 \%$, insomnia $34 \%$ dan tekanan psikologis 71,5\%, sedangkan di Indonesia FIK-UI \& IPKJI (2020) yang muncul adalah perasaan cemas dan tegang sebanyak $70 \%$. Kecemasan yang tinggi ini dapat membuat penurunan imunitas, sehingga tenaga kesehatan sangat beresiko tertular, oleh karena itu tenaga kesehatan harus melakukan upaya mengurangi kecemasan.

Berdasarkan data dari Badan Nasional Penanggulangan Bencana (BNPB) tahun 2020, di Provinsi Bangka Belitung didapatkan pasien terkonfirmasi COVID-19 sebanyak 566 orang dan $7(1,2 \%)$ orang meninggal dunia. Survei yang dilakukan peneliti di Rumah Sakit Umum Daerah Soekarno didapatkan hasil dari 15 orang tenaga kesehatan diantaranya 9 orang (60\%) mengalami perasaaan cemas. COVID-19 memiliki dampak yang besar terhadap tenaga kesehatan. Perawat dan dokter adalah tenaga kesehatan yang paling sering berinteraksi dengan pasien sehingga resiko tertularnya COVID-19 dari pasien ke perawat dan dokter sangatlah besar.

Kecemasan merupakan salah satu penyebab turunnya imunitas pandemi saat ini. Banyak faktor penyebabnya bagi tenaga kesehatan salah satunya adalah keterbatasan ketersediaan Alat Pelindung Diri (APD) sebagai penyebab utamanya (Lai et al., 2020), selain APD tentunya banyak penyebab kecemasan ini. Survei yang dilakukan peneliti pada tanggal 20 Oktober 2020 dengan wawancara langsung mendapatkan hasil bahwa 4 petugas kesehatan merasa cemas ketika mendapat surat tugas untuk jaga di ruang isolasi COVID19, walaupun pendapatan yang ditawarkan lebih besar dibandingkan petugas kesehatan yang jaga di ruang inap biasa. Kecemasan yang ditimbulkan banyak faktor penyebabnya seperti alat pelindung diri terbatas, pasien yang tidak jujur, memikirkan keluarga yang ditinggalkan, tingkat kematian yang cepat. Untuk memberikan pedoman intervensi mengatasi masalah ini tentunya perlu dilakukan penelitian penyebabnya terlebih dahulu, sehingga bisa diatasi berdasarkan penyebab permasalahannya. Penelitian ini bertujuan untuk mengetahui faktor apa saja yang mempengaruhi kecemasan tenaga kesehatan dalam penangan COVID-19.

Hasil penelitian ini tentunya sangat berkontribusi dalam mengatasi permasalahan yang saat ini menjadi permasalahan dunia. Dengan mengetahui faktor yang mempengaruhi kecemasan tenaga kesehatan dalam penanganan COVID-19 sehingga sebagai landasan membuat intervensi menurunkan tingkat kecemasan petugas kesehatan yang akan berdampak pada imunitas sehingga petugas kesehatan tidak mudah terinfeksi virus COVID19 ini. Petugas kesehatan tentunya tidak boleh memperlihatkan kecemasannya sehingga dapat memberikan pelayanan terbaik. Faktor kecemasan yang akan diketahui setelah penelitian akan menjadi perhatian penting untuk meminimalkan petugas terinfeksi.

\section{METODE PENELITIAN}

Penelitian ini akan menggunakan desain penelitian kuantitatif dengan pendekatan cross-sectional. Pendekatan ini dipilih untuk mempelajari dinamika korelasi antara faktorfaktor resiko dengan efek, dengan cara menyebar angket sekaligus pada suatu waktu yang 
bertujuan untuk mengetahui adakah hubungan antara variabel independen (pengetahuan, masa kerja, jenis kelamin, pendidikan, usia, status keluarga dan sarana prasarana) dengan variabel dependen (kecemasan tenaga kesehatan).

Populasi dari penelitian ini adalah semua perawat yang bertugas di 4 Rumah Sakit Rujukan COVID-19 yang bertugas di ruang Isolasi dan UGD yaitu Rumah Sakit Umum Daerah Depati Hamzah Kota Pangkalpinang, RSUD Dr. (H.C) Ir. Soekarno, Rumah Sakit Bakti Timah Pangkalpinang, RSUD Depati Bahrin berjumlah 119 orang. Pengambilan sampel penelitian menggunakan total sampling non random berjumlah 119 orang. Alat pengumpulan data yaitu koesioner yang telah dilakukan uji validitas merujuk pada ZungSelf Anxiety Rating Scale (ZSAS), kuesioner akan dibuat menggunakan google form untuk meminimalkan peneliti kontak langsung dengan responden.

Peneliti mengirimkan surat izin penelitian ke rumah sakit tempat penelitian, selanjutnya pertama yang akan dilakukan peneliti adalah melakukan persamaan persepsi melalui Focus Group Discussion (FGD) yang melibatkan anggota tim peneliti kepada kepala ruangan UGD dan ruang isolasi yang membantu proses penelitian. Diskusi dilakukan untuk mempersamakan persepsi mengenai tujuan penelitian serta rencana proses pelaksanaan kegiatan penelitian seperti memberikan lembar informed consent dan memantau pengisian kuesioner yang dilakukan responden, pembagian masing - masing tugas dalam pengumpulan data.

Pengumpulan data dengan cara kepala ruangan membagikan link google form kuesioner kepada responden yang telah bersedia untuk menjadi responden di masingmasing rumah sakit, semua responden sebelumnya sudah dilakukan kontrak waktu kepada responden. Tahap kedua yaitu memastikan bahwa kuesioner yang diberikan adalah responden yang mengisi sebagai sasaran peneliti dengan melibatkan kepala ruangan yang bertugas di ruang tersebut untuk membantu melihat.

Hasil yang didapat selanjutnya akan dilakukan analisis data dengan menggunakan uji chi square untuk menemukan hubungan antar variabel independen dan dependen. Pengolahan data melalui berbagai tahap; editing, coding, entry dan cleaning. Setelah data di olah akan dilakukan penyusunan laporan dan mempersiapkan manuskrip untuk di lakukan publikasi.

Peneliti telah melakukan penelitian ini berlangsung pada bulan Juli 2021 selama 2 minggu di 4 Rumah Sakit sebagai lahan penelitian yaitu Rumah Sakit Depati Hamzah Pangkalpinang, RSBT Pangkalpinang, RSUD Dr. (H.C) Ir. Soekarno, dan RSUD Depati Bahrin Sungailiat. Ruangan yang dijadikan objek penelitian adalah ruangan rawat inap isolasi COVID 19 dan UGD. Jumlah sampel 119 orang.

\section{HASIL PENELITIAN \\ Analisis Univariat \\ Kecemasan Tenaga Kesehatan}

Tabel. 1

Distribusi Frekuensi Responden

Berdasarkan Kecemasan Tenaga Kesehatan

\begin{tabular}{lcc}
\hline \multicolumn{1}{c}{ Kecemasan Tenaga } & Jumlah & Persentase \\
$\quad$ Kesehatan & & 62,2 \\
\hline Cemas & 74 & 37,8 \\
Tidak Cemas & 45 & 100 \\
\hline Total & 119 & \\
\hline
\end{tabular}


Berdasarkan tabel 1 distribusi frekuensi kecemasan tenaga kesehatan dalam penanganan COVID-19 sebagian besar mengalami kecemasan yaitu 62,2\%

Usia

Tabel. 2

Nilai Rata-rata berdasarkan Usia

\begin{tabular}{lccccc}
\hline Variabel & $\mathrm{n}$ & Mean & SD & Min-Mak & 95\% CI \\
\hline Usia & 119 & 32,71 & 5,627 & $22-50$ & $31,68-33,73$ \\
\hline
\end{tabular}

Berdasarkan tabel 2 nilai rata-rata usia responden berusia 32 tahun. Usia terendah 22 tahun dan yang tertinggi 50 tahun.

\section{Jenis Kelamin}

Tabel. 3

Distribusi Frekuensi Berdasarkan Jenis Kelamin

\begin{tabular}{|c|c|c|}
\hline Jenis Kelamin & Jumlah & Persentase \\
\hline Perempuan & 75 & 63 \\
\hline Laki-laki & 44 & 37 \\
\hline Total & 119 & 100 \\
\hline
\end{tabular}

Bedasarkan tabel 3 distribusi frekuensi jenis kelamin responden sebagian besar berjenis kelamin perempuan $63 \%$.

\section{Pendidikan}

Tabel. 4

Distribusi Frekuensi Berdasarkan Pendidikan

\begin{tabular}{lcc}
\hline \multicolumn{1}{c}{ Pendidikan } & Jumlah & Persentase \\
\hline DIII & 72 & 60,5 \\
S1/Profesi/Dokter & 47 & 39,5 \\
\hline Total & 119 & 100 \\
\hline
\end{tabular}

Berdasarkan tabel 4 distribusi frekuensi pendidikan responden sebagian besar berpendidikan DIII sebanyak 60,5\%

\section{Masa Kerja}

Tabel 5

Distribusi Frekuensi Berdasarkan Masa Kerja

\begin{tabular}{lccc}
\hline & Masa Kerja & Jumlah & Persentase \\
\hline$<3 \mathrm{Th}$ & 26 & 21,8 \\
$3-5 \mathrm{Th}$ & 11 & 9,2 \\
$>5 \mathrm{Th}$ & 82 & 68,9 \\
\hline Total & 119 & 100 \\
\hline
\end{tabular}

Berdasarkan tabel 5 distribusi frekuensi masa kerja sebagian besar memiliki masa kerja $>5$ tahun sebanyak $68,9 \%$. 


\section{Status Keluarga}

Tabel. 6

Distribusi Frekuensi Berdasarkan Status Keluarga

\begin{tabular}{lcc}
\hline \multicolumn{1}{c}{ Status Keluarga } & Jumlah & Persentase \\
\hline Berkeluarga & 87 & 73,1 \\
Tidak Berkeluarga & 32 & 26,9 \\
Total & 119 & 100 \\
\hline
\end{tabular}

Berdasarkan tabel 6 distribusi frekuensi status keluarga responden sebagian besar berkeluarga sebanyak $73,1 \%$

\section{Pengetahuan}

Tabel. 7

Distribusi Frekuensi Berdasarkan Pengetahuan

\begin{tabular}{lcc}
\hline \multicolumn{1}{c}{ Pengetahuan } & Jumlah & Persentase \\
\hline Kurang Baik & 44 & 37.0 \\
Baik & 75 & 63,0 \\
\hline Total & 119 & 100 \\
\hline
\end{tabular}

Berdasarkan tabel 7 distribusi frekuensi pengetahuan responden sebagian besar memiliki pengetahuan baik yaitu $63 \%$.

\section{Sarana Prasarana}

Tabel. 8

Distribusi Responden menurut

Ketersedian Sarana Prasarana

\begin{tabular}{|c|c|c|}
\hline Sarana Prasana & Jumlah & Persentase \\
\hline Tidak Tersedia & 13 & 10.9 \\
\hline Tersedia & 106 & 89,1 \\
\hline Total & 84 & 100 \\
\hline
\end{tabular}

Berdasarkan tabel 8 hampir seluruh responden menilai sarana prasarana tersedia, yaitu $89,1 \%$. Hanya sebagian kecil yang menilai tidak tersedia $(10,9 \%)$.

\section{Analisis Bivariat}

Tabel. 9

Hubungan yang mempengaruhi (Usia) dengan Permasalahan Kecemasan Tenaga Kesehatan dalam Penanganan COVID-19

\begin{tabular}{lccccccc}
\hline \multicolumn{1}{c}{ Variabel } & $\mathrm{n}$ & Mean & SD & Rerata 95\% CI & $t$ & $d f$ & $p$ value \\
\hline Kecemasan & & & & & & & \\
Cemas & 74 & 33,51 & 5,869 & $0,056-0,135$ & 2,034 & 117 & 0,044 \\
Tidak Cemas & 45 & 31,38 & 4,988 & & & & \\
\hline
\end{tabular}


Berdasarkan pada tabel 9 menunjukkan rata-rata skor kecemasan yang mengalami cemas adalah 33,51 (SD = 5,869). Sedangkan rata-rata skor kecemasan yang tidak cemas adalah 31,38 dengan (SD $=4,988)$. Hasil uji statistik didapatkan nilai $p=0,044$ maka dapat disimpulkan bahwa ada perbedaan yang signifikan antara responden yang mengalami cemas dan yang tidak cemas. Pengukuran dilakukan dengan menggunakan uji statistik dependen t-test.

Tabel. 10

Hubungan yang Mempengaruhi (Jenis Kelamin, Pendidikan, Masa Kerja, Status Keluarga, Pengetahuan, Sarana dan Prasarana) dengan Permasalahan Kecemasan Tenaga Kesehatan dalam Penanganan COVID-19

\begin{tabular}{|c|c|c|c|c|c|c|c|c|}
\hline \multirow{2}{*}{\multicolumn{2}{|c|}{ Permasalahan Kecemasan }} & \multicolumn{4}{|c|}{ Kecemasan } & \multirow{2}{*}{\multicolumn{2}{|c|}{ Total }} & \multirow{3}{*}{$\mathrm{P}$ value } \\
\hline & & \multicolumn{2}{|c|}{ Cemas } & \multicolumn{2}{|c|}{ Tidak Cemas } & & & \\
\hline & & $\mathrm{n}$ & $\%$ & $\mathrm{n}$ & $\%$ & $\mathrm{n}$ & $\%$ & \\
\hline \multirow[t]{2}{*}{ Jenis Kelamin } & Perempuan & 45 & 60 & 30 & 40 & 75 & 100 & 0,520 \\
\hline & Laki-laki & 29 & 65,9 & 15 & 34,1 & 44 & 100 & \\
\hline \multirow[t]{2}{*}{ Pendidikan } & DIII & 44 & 61,1 & 28 & 38,9 & 72 & 100 & 0,765 \\
\hline & $\begin{array}{l}\mathrm{S} 1+\text { Ners/Dokt } \\
\text { er }\end{array}$ & 30 & 63,8 & 17 & 36,2 & 47 & 100 & \\
\hline \multirow[t]{3}{*}{ Masa Kerja } & $<3 \mathrm{Th}$ & 15 & 57,7 & 11 & 42,3 & 26 & 100 & 0,703 \\
\hline & 3-5 Th & 6 & 54,4 & 5 & 45,5 & 11 & 100 & \\
\hline & $>5 \mathrm{Th}$ & 53 & 64,6 & 29 & 35,4 & 82 & & \\
\hline \multirow[t]{2}{*}{ Status Keluarga } & Berkeluarga & 59 & 67,8 & 28 & 32,2 & 87 & 100 & 0,037 \\
\hline & $\begin{array}{l}\text { Belum } \\
\text { Berkeluarga }\end{array}$ & 15 & 46,9 & 17 & 53,1 & 32 & 100 & \\
\hline \multirow[t]{2}{*}{ Pengetahuan } & Kurang Baik & 38 & 86,4 & 6 & 13,6 & 44 & 100 & 0,000 \\
\hline & Baik & 36 & 48,0 & 39 & 52,0 & 75 & 100 & \\
\hline Sarana dan & Tidak & 8 & 61,5 & 5 & 38,5 & 13 & 100 & 1,000 \\
\hline \multirow{2}{*}{ Prasarana } & Tersedia & 66 & 62,3 & 40 & 37,7 & 106 & 100 & \\
\hline & Tersedia & & & & & & 100 & \\
\hline
\end{tabular}

Berdasarkan pada tabel 10 dari beberapa faktor yang menjadi dugaan permasalahan kecemasan dalam penanganan COVID-19 yang memiliki hubungan adalah status keluarga dan pengetahuan tenaga kesehatan. Dibuktikan dengan uji statistik menggunakan analisis chi square. Sedangkan variabel jenis kelamin, pendidikan, masa kerja, saran dan prasaran tidak ada hubungan dengan permasalahan kecemasan tenaga kesehatan dalam penangan COVID-19.

Variabel status keluarga didapatkan hasil nilai pvalue 0,037 artinya ada hubungan yang signifikan antara status keluarga responden yang sudah berkeluarga dengan yang belum berkeluarga. Variabel pengetahuan didapatkan hasil nilai pvalue 0,000 artinya ada hubungan yang signifikan antara pengetahuan kurang baik dengan yang berpengetahuan tidak baik.

\section{PEMBAHASAN}

\section{Usia Responde dengan Kecemasan Tenaga Kesehatan dalam Penanganan Covid- 19}

Hasil penelitian menunjukan ada hubungan usia dengan kejadian kecemasan tenaga kesehatan dalam penanganan COVID-19. Menurut penelitian yang dilakukan Fadli et al., 2020 sejalan dengan penelitian ini. Usia merupakan salah satu faktor yang perlu diperhatikan dalam memilih tenaga kesehatan yang bertugas di ruang COVID-19 disebabkan semakin usia dewasa lanjut yang memiliki kerentanan kecemasan tinggi. Penelitian yang dilakukan Puspanegara (2019) mendapatkan hasil ada hubungan antara 
mekanisme koping dengan tingkat kecemasan pasien pada usia kategori dewasa akhir $(0,005)$, dan juga ada hubungan antara mekanisme koping dengan tingkat kecemasan pasien pada usia kategori dewasa akhir $(0,002)$.

Penelitian Astin \& Paembonan (2021) didapatkan hasil penelitian bahwa semakin dewasa usia seseorang, maka semakin berkurang kecemasan yang dialami. Hal tersebut bisa terjadi karena semakin dewasa usia seseorang maka semakin matang proses berpikirnya dalam menghadapi suatu masalah. Selain dari pada itu, pengalaman seseorang terhadap suatu masalah yang pernah dialami akan memberikan perubahan atau perkembangan dalam hidupnya, sehingga ketika menghadapi suatu masalah yang sama seseorang tersebut dapat mengontrol kecemasan yang dialami $(0,000)$.

Peneliti sendiri berpendapat bahwa dari hasil penelitian ini ada hubungan antara usia dengan kecemasan dalam penanganan COVID-19, kaitannya adalah usia muda yang memiliki status belum berkeluarga memiliki kecemasan rendah, sementara usia dewasa awal yang berstatus berkeluarga memiliki tingakat kecemasan lebih tinggi. Usia dari hasil penelitian ini menunjukan ada kaitannya dengan faktor variabel lain dengan status berkeluarga. Usia dalam penelitian ini didapatkan hasil yang usia paling rendah 22 tahun dan yang paling tinggi 50 tahun. Hal ini menunjukkan bahwa semakin usai tua seseorang memiliki rasa cemas yang tinggi dikarenakan memikirkan kondisi fisik yang kurang baik sehingga memiliki kecendrungan untuk merasa cemas lebih tinggi daripada usia muda.

\section{Status Keluarga dengan Kecemasan Tenaga Kesehatan dalam Penanganan COVID-19}

Status keluarga merupakan status perkawinan yang memberikan identitas seseorang sudah memiliki pasangan hidup berkeluarga dengan lawan jenis. Menurut Kamus Besar Bahasa Indonesia (KBBI) status berkeluarga merupakan berumah tangga atau mempunyai keluarga. Hasil penelitian ini didapatkan hasil bahwa status keluarga mempunya hubungan terhadap kecemasan tenaga kesehatan dalam memberikan penanganan COVID-19 $(0,037)$. Seseorang yang memiliki keluarga tempat tinggal memiliki resiko rasa cemas dikarenakan pemikiran yang menularkan setelah pulang dari tempat kerja dalam penanganan COVID19. Menurut penelitian yang dilakukan Astin \& Paembonan (2021) mendapatkan hasil penelitian yang telah dilakukan terhadap perawat yang bertugas dalam penanganan pasien COVID-19 di Rumah Sakit Siloam Makassar, yang dianalisis menggunakan uji statistic chi square dan dilanjutkan dengan uji alternatif kolmogorof smirnov, maka diperoleh nilai $\mathrm{p}=$ 0,01 sehingga $\mathrm{p}<\propto$ maka dapat disimpulkan bahwa ada hubungan antara status pernikahan dengan kecemasan perawat dalam menangani pasien COVID-19 di Rumah Sakit Siloam Makassar, dari hasil penelitian yang dilakukan terhadap responden terdapat cemas berat lebih banyak dialami oleh responden yang sudah menikah dibandingkan dengan responden yang belum menikah. Sejalan dengan penelitian yang dilakukan Fadli et al., (2020) bahwa ada hubungan responden yang sudah menikah dengan kecemasan dalam penanganan COVID-19.

Peneliti sendiri berpendapat bahwa dari hasil penelitian ini menunjukan 67,8\% yang berstatus berkeluarga mengalami kecemasan ketika bertugas dalam penanganan COVID19. Kecemasan ini timbul ketika dalam memberikan pelayanan terhadap pasien COVID-19, tenaga kesehatan merasa takut menularkan ke keluarga yang ada di rumah. Banyak tindakan yang harus dilalui tenaga kesehatan ketika pulang ke rumah, harus mandi terlebih dahulu sebelum berkumpul dengan keluarga, harus melakukan cek rutin dengan status kesehatannya, dengan kondisi seperti ini membuat tenaga kesehatan merasakan kecemasan. Kecemasan yang timbul akan memberikan kondisi yang kurang baik sehingga menyebabkan imunitas menurun. 


\section{Pengetahuan dengan Kecemasan Tenaga Kesehatan dalam Penanganan COVID-19}

Menurut Yuliana (2017) pengetahuan adalah hasil penginderaan manusia, atau hasil tahu seseorang terhadap objek melalui indera yang dimiliki (mata, hidung, telinga, dan sebagainya). Di dalam penelitian ini mengungkapkan pengetahuan yang berkaitan dengan COVID-19, pencegahan tertularnya, pelaksanaan dalam penanganan pada pasien COVID19. Hasil penelitian ini menunjukan bahwa ada hubungan antara pengetahuan tenaga kesehatan terhadap kecemasan dalam penanganan COVID-19 terbukti nilai $p$ value $=0,000$.

Menurut penelitian yang dilakukan oleh Fadli et al., 2020 mendapatkan hasil ada hubungan antara pengetahuan tenaga kesehatan dengan kecemasan penangan COVID-19 didapatkan hasil $p$-value $=0,030$. Penelitian yang dilakukan oleh Faizal et al., 2021 didapatkan hasil bahwa pengetahuan masyarakat tentang COVID-19 berhubungan dengan kecemasan yang timbul.

Peneliti berpendapat dari hasil penelitian ini menunjukan bahwa tenaga kesehatan yang menjadi responden dalam penelitian ini sudah memiliki pengetahuan yang cukup baik, kecemasan yang timbul diakibatkan banyak berita-berita hoak dari sosial media yang membuat kecemasan timbul. Sehingga perlunya penyaringan informasi yang masuk sehingga meminimalkan resiko terjadinya kecemasan yang berlebihan.

\section{Jenis Kelamin, Pendidikan, Masa Kerja, Sarana dan Prasarana dengan Kecemasan Tenaga Kesehatan dalam Penanganan COVID-19}

Beberapa variabel yang tidak memiliki hubungan dengan kecemasan dari hasil penelitian ini adalah jenis kelamin, pendidikan, masa kerja dan sarana serta prasarana. Jenis kelamin merupakan perbedaan fisik manusia, dalam penangan COVID-19 ini baik laki-laki maupun perempuan tidak memiliki perbedaan rasa kecemasan yang timbul didapatkan hasil $p$-value $=0,520$ sehingga dapat disimpulkan respon kecemasannya pada jenis kelamin tidak memiliki hubungan. Pendidikan merupakan jenjang pendidikan yang ditempuh seseorang memperoleh penddikan formal, untuk variabel ini juga tidak ada hubungan dengan kecemasan dengan hasil $p$-value $=0,756$. Masa kerja merupakan lamanya seseorang bekerja hal ini menunjukan tidak ada hubungan dengan rasa cemas yang timbul pada saat melakukan penangan COVID-19. Sarana dan prasarana menunjukan tidak ada hubungan karena hasil penelitian menunjukan sarana dan prasarana sudah mencukupi untuk melakukan penanganan COVID-19.

\section{SIMPULAN}

Terdapat 3 variabel yang memiliki hubungan terhadap kecemasan dalam penanganan COVID-19 yaitu usia, status berkeluarga dan pengetahuan tenaga kesehatan. Jenis kelamin, pendidikan, masa kerja, saran dan prasarana tidak memiliki hubungan terhadap kecemasan yang timbul.

\section{SARAN}

Hasil penelitian ini bisa menjadi pedoman dalam menunjukan sumber daya manusia atau tenaga kesehatan untuk ditempatkan di ruangan yang memberikan pelayanan COVID19 seperti kriteria usia dan status berkeluarga. Untuk variabel pengetahuan disarankan memberikan informasi penyegaran bagi tenaga kesehatan yang akan ditempatkan di ruangan COVID-19. 


\section{DAFTAR PUSTAKA}

Astin, A., \& Paembonan, A. (2021). Faktor yang Berhubungan dengan Tingkat Kecemasan Perawat dalam Penanganan Pasien Covid-19 di Rumah Sakit Siloam Makassar. Jurnal Keperawatan Florence Nightingale, 4(1), 31-35. https://doi.org/10.52774/jkfn.v4i1.60

Fadli, F., Safruddin, S., Ahmad, A. S., Sumbara, S., \& Baharuddin, R. (2020). Faktor yang Mempengaruhi Kecemasan pada Tenaga Kesehatan dalam Upaya Pencegahan Covid19. Jurnal Pendidikan Keperawatan Indonesia, 6(1), 57-65. https://doi.org/10.17509/jpki.v6i1.24546

Faizal, K. M., Triaspodo, K., \& Meilando, R. (2021). Pengetahuan DAN Kecemasan Masyarakat tentang Covid -19. Citra Delima: Jurnal Ilmiah STIKES Citra Delima Bangka Belitung, 5(1), 38-44. https://doi.org/10.33862/citradelima.v5i1.234

Huang, C., Wang, Y., Li, X., Ren, L., Zhao, J., Hu, Y., Zhang, L., Fan, G., Xu, J., Gu, X., Cheng, Z., Yu, T., Xia, J., Wei, Y., Wu, W., Xie, X., Yin, W., Li, H., Liu, M., \& Cao, B. (2020). Clinical features of patients infected with 2019 novel coronavirus in Wuhan, China. The Lancet, 395(10223), 497-506. https://doi.org/10.1016/S01406736(20)30183-5

Fik-UI \& IPKJI . (2020). Data Psikologis Covid-19

Kemenkes. (2020). Situasi Terkini Perkembangan Coronavirus Disease (Covid-19). Infeksi Emergngi

Lai, J., Ma, S., Wang, Y., Cai, Z., Hu, J., Wei, N., Wu, J., Du, H., Chen, T., Li, R., Tan, H., Kang, L., Yao, L., Huang, M., Wang, H., Wang, G., Liu, Z., \& Hu, S. (2020). Factors associated with mental health outcomes among health care workers exposed to coronavirus disease 2019. JAMA Network Open, 3(3), 1-12. https://doi.org/10.1001/jamanetworkopen.2020.3976

Yuliana, E. (2017). Analisis Pengetahuan Siswa tentang Makanan yang Sehat dan Bergizi terhadap Pemilihan Jajanan di Sekolah. Jurnal Ilmiah Keperawatan, 5(1), 22-31. http://repository.ump.ac.id/4114/3/Erlin\%20Yuliana_BAB\%20II.pdf

Puspanegara, A. (2019). Pengaruh Usia terhadap Hubungan Mekanisme Koping dengan

Kecemasan Ketika Menjalani Terapi Hemodialisa bagi Para Penderita Gagal Ginjal Kronik di Kabupaten Kuningan Jawabarat. Jurnal Ilmu Kesehatan Bhakti Husada: Health Sciences Journal, 10(2), 135-142. https://doi.org/10.34305/jikbh.v10i2.102 WHO. (2020). Data Covid-19.www.who.official.go.id 